\title{
A PRODUÇÃO CIENTÍFICA SOBRE EDUCAÇÃO INDÍGENA NO BRASIL: UMA REVISÃO NARRATIVA
}

\author{
LA PRODUCCIÓN CIENTÍFICA SOBRE EDUCACIÓN INDÍGENA EN BRASIL: \\ UNA REVISIÓN NARRATIVA
}

THE SCIENTIFIC PRODUCTION ON INDIGENOUS EDUCATION IN BRAZIL: A NARRATIVE REVIEW

\author{
Alexandre Masson MAROLDI ${ }^{1}$ \\ Luis Fernando MAIA LIMA ${ }^{2}$ \\ Maria Cristina Piumbato Innocentini HAYASHI ${ }^{3}$
}

RESUMO: A educação indígena no Brasil tem o seu marco fundador com as primeiras ações catequéticas dos jesuítas na segunda metade do século XVI. Nessa longa trajetória até os dias atuais a educação dos povos indígenas que habitam o território brasileiro tem sido alvo de controvérsias e discussões, tanto no nível governamental quanto acadêmico, e gerado inúmeros estudos. O objetivo desse trabalho foi identificar e descrever por meio de uma revisão narrativa a produção científica produzida pelos pesquisadores que se dedicam a estudar o tema e publicaram seus estudos em diferentes canais de publicação: teses e dissertações, livros, coletâneas e artigos. Ao final do trabalho foi possível identificar uma produção científica composta de várias tipologias documentais acerca da temática educação indígena oriunda de diversas áreas do conhecimento.

PALAVRAS-CHAVE: Educação indígena. Produção científica. Revisão narrativa.

RESUMEN: La educación indígena en Brasil tiene su marco fundador con las primeras acciones catequéticas de los jesuitas en la segunda mitad del siglo XVI. En esa larga trayectoria hacia hoy día, la educación de los pueblos indígenas que habitan el territorio brasileño ha sido objeto de controversias y discusiones, tanto a nivel gubernamental como académico y generado innumerables estudios. El objetivo de este trabajo es identificar y describir por medio de una revisión narrativa la producción científica producida por los investigadores que se dedican a estudiar el tema y publicaron sus estudios en diferentes canales de publicación: tesis y disertaciones, libros, colecciones y artículos. Al final del trabajo se pudo identificar una producción científica compuesta de varias tipologías documentales acerca de la temática educación indígena oriunda de diversas áreas del conocimiento.

\footnotetext{
${ }^{1}$ Universidade Federal de Rondônia (UNIR), Porto Velho - RO - Brasil. Professor do Departamento de Ciência da Informação. ORCID: <http://orcid.org/0000-0002-6592-7750>. E-mail: alexandre@unir.br

${ }^{2}$ Universidade Federal de Rondônia (UNIR), Porto Velho - RO - Brasil. Professor do Departamento de Economia. ORCID: <http://orcid.org/0000-0002-4208-4914>. E-mail: maialima2000@ gmail.com

${ }^{3}$ Universidade Federal de São Carlos (UFSCar), São Carlos - SP - Brasil. Professora do Departamento de Ciência da Informação e Programa de Pós-graduação em Educação. ORCID: <http://orcid.org/0000-00031250-3767>.E-mail: dmch@ufscar.br
} 
PALABRAS CLAVE: Educación indígena. Producción científica. Revisión narrativa.

ABSTRACT: The indigenous education in Brazil has its founding milestone with the first catechetical actions of the Jesuits in the second half of the XVI. In this long trajectory until the days the education of the indigenous peoples that inhabit the Brazilian territory has been the object of controversies and discussions, both at governmental and academic level and generated numerous studies. The aim of this work was to identify and describe, through a narrative review, the scientific production produced by the researchers who study the subject and published their studies in different publication channels: theses and dissertations, books, collections and articles. At the end of the study it was possible to identify a scientific production composed of several documentary typologies about the theme of indigenous education from several areas of knowledge.

KEYWORDS: Indigenous education. Scientific production. Narrative review.

\section{Introdução}

Desde a segunda metade do século XVI quando chegaram ao país os primeiros jesuítas da Companhia de Jesus chefiados pelo padre Manoel da Nóbrega, enviados de Portugal por D. João III, esses missionários tinham como objetivo converter os nativos à fé cristã. No entanto, a ação pedagógica desenvolvida pelos jesuítas não visava somente à catequização dos indígenas, mas era uma forma de inculcar a cultura letrada do colonizador, conforme argumentam os inúmeros estudiosos da educação jesuítica no Brasil colonial (BITTAR; FERREIRA JUNIOR 2004).

A partir de então deu-se início a um processo de desagregação dos povos indígenas, pois a educação indígena tal como era praticada nas aldeias fora desqualificada pelo colonizador. Conforme argumenta Freire (2004, p. 11), ao ignorar as concepções pedagógicas indígenas adotadas por mais de 1.200 povos os missionários não admitiram a possibilidade "de índios e índias terem sido capazes de construir, ao longo do tempo, um discurso sobre suas próprias práticas educativas".

Em vista disso, Oliveira e Nascimento, (2012, p. 768) relatam que “o principal objetivo das políticas educativas voltadas para os povos indígenas, das ações catequéticas dos jesuítas no período colonial às práticas indigenistas do século $\mathrm{XX}$, era trazê-los à civilização ou nacionalizá-los”. Ou seja, na maior parte da longa história da educação indígena, “aos índios eram oferecidos serviços educacionais para mudar o que são e para serem integrados à sociedade que os envolvem". (COHN, 2005, p. 486). 
Desde então, a temática da educação indígena tem sido bastante explorada, seja em relatórios técnicos produzidos por órgãos governamentais de planejamento e execução de políticas educacionais voltadas para essa população, seja em trabalhos acadêmicos que resultam de pesquisas realizadas em nível de pós-graduação ou em artigos divulgados em periódicos científicos.

Em um balanço sobre a produção científica sobre a educação indígena realizado por D’Angelis (2008), o autor chama a atenção para o fato de que não são poucas as páginas que se têm preenchido a respeito da educação escolar indígena. Contudo, D'Angelis (2008, p.29) alertava que as publicações acerca da temática educação indígena "precisam ser lidas ou compreendidas no conjunto das demais para se construir, com isso, um painel dos caminhos e descaminhos da educação indígena no Brasil". Nesse sentido, esse trabalho se propõe realizar uma revisão narrativa procurando identificar a produção científica em educação indígena.

\section{Procedimentos metodológicos}

A revisão narrativa permite "estabelecer relações com produções anteriores, identificando temáticas recorrentes, apontando novas perspectivas, consolidando uma área de conhecimento" (VOSGERAU; ROMANOWSKI, 2014, p. 170), bem como descrever "o 'estado da arte' de determinado assunto, sob o ponto de vista teórico ou conceitual" (ROTHER, 2007, p. 5), de acordo com a análise crítica pessoal do autor que realiza esse tipo de estudo.

O eixo norteador para seleção dos trabalhos foi constituído pelos autores que pesquisaram sobre a educação indígena, isto é: teses e dissertações, livros, coletâneas, dossiês temáticos publicados em periódicos científicos, bem como artigos que apresentaram balanços críticos da produção científica sobre a temática. Essas publicações foram coletadas em diferentes fontes de informação e de acordo com as seguintes estratégias de busca: a) busca retrospectiva, por meio da leitura das listas de referências das obras que foram objeto de estudo para a elaboração da introdução e das seções subsequentes desse trabalho, e busca prospectiva, que consistiu em buscar novos estudos que citaram os documentos já selecionados, conforme sugerem Dresh, Lacerda e Valle Junior (2015); b) por meio de pesquisa no Google Acadêmico, escolhido por ser uma ferramenta de busca na Web que recupera artigos revisados por especialistas, editores, 
teses, livros, resumos e artigos de editoras acadêmicas, organizações profissionais, bibliotecas de pré-publicações, universidades e outras entidades acadêmicas; c) por meio de pesquisa na biblioteca eletrônica SciELO, que abrange uma coleção selecionada de 356 títulos de periódicos científicos brasileiros. Essas buscas foram realizadas até atingirem $o$ ponto de saturação, ou seja, quando os estudos encontrados deixaram de contribuir para o processo de síntese do conhecimento sobre a temática pesquisada, ou então quando os resultados obtidos passaram a ser repetitivos.

Para recuperação das publicações no Google Acadêmico e na SciELO foram utilizadas as expressões de busca "educação escolar indígena" e "educação indígena", de acordo com os seguintes critérios: páginas em português; sem restrição aos tipos de documentos; disponibilidade do texto integral dos documentos; recorte temporal anterior a $1996^{4}$ somente para teses e dissertações; e exclusão de registros que não atendiam ao escopo da pesquisa.

\section{Dissertações e teses sobre educação indígena no Brasil: 1975-1995}

Um trabalho pioneiro no Brasil acerca do estado da arte da educação indígena foi elaborado por Marta Valéria Capacla (1995). Essa obra, intitulada $O$ debate sobre a educação indígena no Brasil (1975-1995) e editada pelo Grupo de Educação Indígena da Universidade de São Paulo (MARI) em parceria com o MEC. Nessa publicação, a autora elencou 13 trabalhos publicados entre os anos de 1975 e 1995. São livros (n=2), dissertações $(n=6)$, teses $(n=1)$, e coletâneas $(n=4)$ que trataram do tema. Quase uma década depois, no inventário de trabalhos de pós-graduação sobre educação escolar indígena no Brasil realizado por Grupioni (2003b), o autor identificou mais seis dissertações de mestrado e quatro teses de doutorado defendidas entre 1990 e 1995. Portanto, no período entre 1978 e 1995, do total $(n=17)$ de pesquisas de pós-graduação realizadas sobre educação indígena, as de mestrado $(n=12)$ foram superiores às de doutorado ( $\mathrm{n}=5)$, de acordo com esses dois levantamentos. (Quadro 1).

Conforme menciona Grupioni (2003b, p.197), as temáticas desses trabalhos "têm relação com os processos de instituição escolar em terras indígenas e suas implicações" e abordam desde "questões suscitadas pelo uso, ou não, das línguas indígenas nas escolas",

\footnotetext{
${ }^{4}$ As teses e dissertações recuperadas após esse ano, totalizando 173 trabalhos, já foram analisadas e serão objeto de outro artigo em fase de elaboração.
} 
bem como "trabalhos que dizem respeito aos processos tradicionais de socialização das crianças indígenas”.

Quadro 1: Trabalhos de pós-graduação sobre educação indígena (1978-1995)

\begin{tabular}{|c|c|c|}
\hline $\begin{array}{l}\text { Autor /Ano } \\
\text { /Nível* }\end{array}$ & $\begin{array}{l}\text { Área / } \\
\text { Instituição }\end{array}$ & Escopo do Trabalho \\
\hline $\begin{array}{c}\text { Tsupal } \\
1978 / \mathrm{M} \\
\end{array}$ & $\begin{array}{c}\text { Educação } \\
(\text { UnB })\end{array}$ & $\begin{array}{l}\text { Descrição dos processos de educação bilíngue entre os Karajá e } \\
\text { Xavante. }\end{array}$ \\
\hline $\begin{array}{c}\text { Assis } \\
1981 / \mathrm{M}\end{array}$ & $\begin{array}{l}\text { Antropologia } \\
\text { (UnB) }\end{array}$ & $\begin{array}{l}\text { Analise da presença da escola entre os Galibi e Karipuna, da } \\
\text { região do Uaçá, Amapá. }\end{array}$ \\
\hline $\begin{array}{c}\text { Cunha } \\
1990 / \mathrm{M}\end{array}$ & $\begin{array}{c}\text { Educação } \\
(\text { UnB })\end{array}$ & $\begin{array}{l}\text { Análise do papel exercido pelas escolas mantidas pelo Estado em } \\
\text { terras indígenas. }\end{array}$ \\
\hline $\begin{array}{c}\text { Maher } \\
\text { 1990/M }\end{array}$ & $\begin{array}{l}\text { Linguística } \\
\text { (Unicamp) }\end{array}$ & $\begin{array}{l}\text { Análise um curso de português oral como segunda língua para } \\
\text { jovens Guarani, em São Paulo. }\end{array}$ \\
\hline $\begin{array}{l}\text { Resende } \\
1992 / \mathrm{D}\end{array}$ & $\begin{array}{l}\text { Geografia Humana } \\
\text { (Universidade de } \\
\text { Barcelona) }\end{array}$ & $\begin{array}{l}\text { Baseia-se no princípio geral de que cada aluno antes de entrar na } \\
\text { escola já possui um saber espacial geográfico próprio, fruto de } \\
\text { sua experiência de vida, isto é, de seu lugar no processo social do } \\
\text { trabalho e da cultura. }\end{array}$ \\
\hline $\begin{array}{l}\text { Ferreira } \\
1992 / M\end{array}$ & $\begin{array}{l}\text { Antropologia } \\
\text { (USP) }\end{array}$ & $\begin{array}{l}\text { Aborda questões relacionadas à oralidade e escrita, cultura e } \\
\text { cognição, e propõe uma periodização da educação indígena no } \\
\text { Brasil. }\end{array}$ \\
\hline $\begin{array}{l}\text { Barros } \\
1993 / \mathrm{D}\end{array}$ & $\begin{array}{l}\text { Ciências Sociais } \\
\text { (Unicamp) }\end{array}$ & $\begin{array}{l}\text { Trata de diferentes formas de uso da linguística estrutural no } \\
\text { interior da missão evangélica Summer Institute of Linguistics } \\
\text { (SIL), entre as décadas de 1930 e } 1960 \text {. }\end{array}$ \\
\hline $\begin{array}{l}\text { Ferreira Netto } \\
\quad 1994 / \mathrm{D}\end{array}$ & $\begin{array}{l}\text { Linguística } \\
\text { (USP) }\end{array}$ & $\begin{array}{l}\text { Defende a ideia de que cabe exclusivamente aos índios a opção } \\
\text { por qual tipo de escola eles irão adotar, baseado no princípio de } \\
\text { não interferência que sustenta esta relação de convívio. }\end{array}$ \\
\hline $\begin{array}{l}\text { Monte } \\
\text { 1994/M }\end{array}$ & $\begin{array}{l}\text { Educação } \\
\text { (UFF) }\end{array}$ & $\begin{array}{l}\text { Resgatou, no cotidiano da sala de aula, o currículo construído na } \\
\text { prática pelos professores. Analisa o processo de apropriação da } \\
\text { escrita e de saberes e formas de pensamento não-indígenas } \\
\text { através do exercício dos diários. }\end{array}$ \\
\hline $\begin{array}{l}\text { Leite } \\
\text { 1994/M }\end{array}$ & $\begin{array}{l}\text { Educação } \\
\text { (UFMT) }\end{array}$ & $\begin{array}{l}\text { Relato e análise da experiência, realizada em } 1987 \text { pelos } \\
\text { professores Ticuna, de construção coletiva de um livro com textos } \\
\text { bilíngues para a pós-alfabetização em suas escolas. }\end{array}$ \\
\hline $\begin{array}{l}\text { Pereira } \\
1994 / \mathrm{D}\end{array}$ & $\begin{array}{l}\text { Psicologia } \\
\text { (USP) }\end{array}$ & $\begin{array}{l}\text { Investiga a socialização secundária de crianças pertencentes ao } \\
\text { grupo indígena Kaingang visando identificar variáveis do } \\
\text { processo psicossocial. }\end{array}$ \\
\hline $\begin{array}{l}\text { Borges } \\
1995 / \mathrm{D}\end{array}$ & $\begin{array}{c}\text { Letras } \\
\text { (Universidade de } \\
\text { Utrecht-Holanda) }\end{array}$ & $\begin{array}{l}\text { Elabora uma síntese da etno-história dos Terena para resgatar os } \\
\text { precedentes da educação escolar indígena, e analisar a influência } \\
\text { do Estado e da Igreja nessa realidade educacional. }\end{array}$ \\
\hline $\begin{array}{l}\text { Carvalho } \\
1995 / \mathrm{M} \\
\end{array}$ & $\begin{array}{c}\text { Educação } \\
\text { (UFSM) }\end{array}$ & $\begin{array}{l}\text { Tentativa de desenvolver uma história da educação escolar } \\
\text { indígena do povo Terena. }\end{array}$ \\
\hline $\begin{array}{l}\text { Freitas } \\
1995 / M\end{array}$ & $\begin{array}{l}\text { Linguística } \\
\text { (UFPE) }\end{array}$ & $\begin{array}{l}\text { Analisa o bilinguismo dos Arara e identifica a língua como um } \\
\text { dos elementos que mais resiste ao com os elementos culturais da } \\
\text { sociedade envolvente. }\end{array}$ \\
\hline $\begin{array}{l}\text { Mendes } \\
\text { 1995/M }\end{array}$ & $\begin{array}{l}\text { Linguística } \\
\text { Aplicada } \\
\text { (Unicamp) }\end{array}$ & $\begin{array}{l}\text { Estudo interdisciplinar integrando as áreas da linguística aplicada } \\
\text { e educação matemática visa oferecer subsídios à formação e } \\
\text { atuação de professores não-índios que atuam com professores } \\
\text { índios. }\end{array}$ \\
\hline $\begin{array}{l}\text { Silva, M. } \\
\text { 1995/M }\end{array}$ & $\begin{array}{l}\text { Linguística } \\
\text { (UFG) }\end{array}$ & $\begin{array}{l}\text { Analisa a atitude de duas comunidades Karajá com relação às } \\
\text { duas línguas em contato: Karajá e portuguesa, a facilidade } \\
\text { linguística e os usos dessas línguas nos diferentes domínios } \\
\text { sociais e nas interações intra e intergrupos, bem como as funções } \\
\text { da linguagem escrita nessas comunidades. }\end{array}$ \\
\hline
\end{tabular}




\begin{tabular}{|c|c|l|}
\hline $\begin{array}{c}\text { Silva, T. } \\
1995 / M\end{array}$ & $\begin{array}{c}\text { Educação } \\
\text { (UFMT) }\end{array}$ & $\begin{array}{l}\text { Focaliza a educação escolar salesiana entre os Xavante que vivem } \\
\text { na Terra Indígena Sangradouro, leste de Mato Grosso com vistas } \\
\text { à recuperar essa história. }\end{array}$ \\
\hline
\end{tabular}

Fonte: Elaborado pelos autores

(*) $\mathrm{M}=$ mestrado; $\mathrm{D}=$ Doutorado.

O Quadro 1 mostra a preponderância das pesquisas de mestrado $(n=12)$ sobre as de doutorado $(n=5)$, e também permitem observar que as pesquisas de pós-graduação foram desenvolvidas em várias áreas de conhecimento, como a Psicologia, Geografia, Letras, Ciências Sociais, entre outras. Contudo, é na área de Educação $(n=6)$, que se concentra o maior número de trabalhos, seguida pela área de Linguística $(n=4)$.

O Quadro 1 também mostra que há um intervalo temporal entre as duas primeiras dissertações - a de Tsupal (1978) e a de Assis (1981) - e os demais trabalhos que ocorreram quase uma década após, ou seja, nos anos 1990. É válido mencionar que a expansão e crescimento da pós-graduação brasileira ocorreram principalmente nos anos 1990, conforme mostram os dados de Alves e Oliveira (2014, p. 367), apontando que "no período de 1976 a 1990, o número de cursos havia saltado de 673 para 1.485”, sendo que "na primeira metade dos anos 1990, o crescimento não foi tão acentuado, passando de 1.485, em 1990, para 1.624, em 1996. Todavia, no período de 1996 a 2004, registra-se novamente um crescimento expressivo, passando de 1.624 para 2.993".

Na visão de Grupioni (2008, p.20), os dois primeiros trabalhos de pós-graduação citados no Quadro 1 sobre educação indígena tiveram grande impacto nas publicações futuras,

[...] como precursores da reflexão sistemática sobre a educação indígena, em nível de pós-graduação, na universidade, tanto pelo viés cronológico, já que foram os primeiros, quanto pelo impacto que tiveram na produção subsequente. Os trabalhos de Assis (1981), Cunha (1990) e Ferreira (1992) marcariam a produção imediatamente posterior, que então se diversifica e amplia de forma surpreendente nos anos seguintes.

Sobre esses primeiros trabalhos de pós-graduação, Luciano (2011, p. 51) destaca o interesse comum:

[...] pela compreensão dos processos de escolarização dos povos indígenas e os respectivos impactos na vida individual e coletiva dos indígenas, inclusive as diferentes reações e modos de percepção e interação com o mundo da instituição escolar e os conhecimentos e valores trabalhados por ela. Pode-se então imaginar que as preocupações estavam voltadas para acompanhar o desenvolvimento da entrada da escola na vida desses povos enquanto elemento ou mesmo instrumento de contato e colonização. 
Na segunda metade dos anos de 1990, Grupioni (2008, p. 21) afirma que era praticamente impossível acompanhar todas as publicações da área, uma vez que a comunidade científica interessada na temática havia se expandido significativamente, bem como as temáticas estudadas e as abordagens teóricas empregadas.

Este fato também é corroborado Silva (2016, p. 48), que afirma que entre os anos 1991 a 2010 "ocorreu um boom na produção científica, com um salto significativo sobre a educação indígena, provavelmente ocasionado pela intensificação dos debates sobre os direitos dos povos indígenas no cenário internacional, que desencadearam os movimentos indígenas e indigenistas".

Em relação ao conteúdo e abordagens das teses e dissertações sobre educação indígena, Grupioni (2008, p. 21) comenta que uma parcela considerável desses trabalhos “está focada na análise etnográfica de situações particulares, envolvendo uma única comunidade ou povo indígena em sua experiência de conviver com a escola e a educação indígena", notando-se "poucos trabalhos comparativos e, em menor número ainda, os que buscam uma abordagem mais ampla". Na visão do autor:

Um número expressivo de pesquisas apresenta-se com o intuito de "colaborar", "subsidiar" e "apoiar" intervenções em contextos étnicos particulares, fruto do trabalho de reflexão de pessoas que estão ou estiveram à frente de processos de implantação de escolas ou de formação de professores indígenas, na qualidade de assessores, formadores, docentes ou desenvolvendo outros tipos de trabalhos de intervenção, inclusive missionária, junto a certos grupos indígenas. (GRUPIONI, 2008, p. 21)

No entendimento desse autor isso ocorre pelo fato de que "boa parte dos autores é também assessor de programas de educação indígena, que conduzem seu esforço de reflexão teórica, com o intuito de repensar a própria prática" (GRUPIONI, 2008, p. 21).

Em resumo, as dissertações e teses sobre educação indígena analisada, principalmente nos trabalhos de Capacla (1995), Grupioni (2003a; 2008) e posteriormente em vários outros trabalhos que realizaram "balanços" dessa produção científica, poderia ser dividida em dois momentos: o inicial, com os dois estudos pioneiros de Tsupal em 1978 e Assis em 1981; e em seguida, os trabalhos desenvolvidos a partir da década de 1990, já na esteira das mudanças provocadas pelas conquistas no campo dos direitos indígenas no país, motivadas pela Constituição Federal de 1988, conforme refere Luciano (2011, p. 51): 
Desse modo, essa ampliação paulatina da produção acadêmica sobre a educação escolar indígena acompanha a evolução política do país neste período pós-ditadura e sob as novas orientações legais e políticas da nova Constituição Federal. Os governos passaram a ter mais sensibilidades e conferir maior atenção às questões relativas aos segmentos sociais historicamente excluídos das políticas públicas, dentre os quais, os povos indígenas.

Luciano (2011, p. 52) também identifica que os trabalhos acadêmicos acompanharam o processo de ampliação dos direitos, o que se traduz por uma mudança no enfoque temático dos trabalhos acadêmicos quando se comparam aqueles das décadas de 1980 e 1990 e os da década posterior (2000-2010). Na visão do autor:

Se nas décadas de 1980 e 1990 as preocupações estavam voltadas para estudos de caso etnográficos das experiências dos povos indígenas com a escola muito tendentes a valorizá-los ora como heróis resistentes, ora como vítimas passivas, nesta atual década percebem-se preocupações mais voltadas aos desafios do protagonismo e apropriação da escola e dos processos de formação acadêmica, acompanhando as novas ideias que circulam nos espaços de debates, mas principalmente nos ambientes de discussão de políticas públicas, tais como os de "educação como direito", "cidadania indígena", "indígenas como sujeitos de direito", dentre outros. A escola passa a ser tratada como instrumento de direitos e de cidadania. (LUCIANO, 2011, p. 52).

No balanço realizado por Grupioni (2003a, p. 197), esse autor também comenta que a temática da educação indígena “adquiriu importância acadêmica compondo um campo de saber interdisciplinar, com um volume crescente de pesquisas sendo realizadas e com resultados sendo compartilhados". Esse autor ainda argumenta que os trabalhos ao tratarem de uma "reflexão sobre a própria prática", acabam "gerando uma produção acadêmica mais engajada e comprometida com questões indigenistas e de intervenção social". (GRUPIONI, 2008, p. 22).

\section{Dissertações e teses defendidas por indígenas: 1996-2014}

Luciano (2011) traçou um breve panorama da produção acadêmica sobre educação indígena no Brasil e no Alto Rio Negro em sua tese de doutorado. O autor parte do inventário de Grupioni (2008), mas acrescenta trabalhos de pós-graduação e outros tipos de publicação que apareceram posteriormente. Destaca como novidades nessa produção os primeiros trabalhos acadêmicos de pós-graduação realizados por indígenas em várias áreas de conhecimento. Tendo como base a pesquisa de Luciano (2011), e complementando com 
informações coletadas na literatura científica sobre educação indígena, o Quadro 2 apresenta um panorama de alguns desses trabalhos de pós-graduação defendidas por indígenas.

Quadro 2: Dissertações e teses defendidas por indígenas

\begin{tabular}{|c|c|c|c|}
\hline Autor/Etnia & Ano/Nível & Área/Instituição & Síntese da pesquisa \\
\hline $\begin{array}{c}\text { Darlene } \\
\text { Taukane } \\
\text { (Kurâ-Bakari) } \\
\end{array}$ & $\begin{array}{c}1996 \\
\text { Mestrado }\end{array}$ & $\begin{array}{l}\text { Educação } \\
\text { (UFMT) }\end{array}$ & Focaliza a educação escolar entre os Kurâ-Bakari. \\
\hline $\begin{array}{l}\text { Francisca Pinto } \\
\text { de Ângelo } \\
\text { (Pareci) }\end{array}$ & $\begin{array}{l}2005 \\
\text { Mestrado }\end{array}$ & $\begin{array}{l}\text { Educação } \\
\text { (UFMT) }\end{array}$ & $\begin{array}{l}\text { Institucionalização da educação indígena no } \\
\text { estado de Mato Grosso. }\end{array}$ \\
\hline $\begin{array}{l}\text { Lúcia Alberta } \\
\text { Andrade de } \\
\text { Oliveira (Baré) }\end{array}$ & $\begin{array}{l}2005 \\
\text { Mestrado }\end{array}$ & $\begin{array}{l}\text { Educação } \\
\text { (UFAM) }\end{array}$ & $\begin{array}{l}\text { Programas de educação escolar indígena que } \\
\text { foram desenvolvidos no Alto Rio Negro, } \\
\text { município de São Gabriel da Cachoeira/AM nos } \\
\text { finais dos anos } 1990 \text {. }\end{array}$ \\
\hline $\begin{array}{l}\text { Maria das Dores } \\
\text { Oliveira } \\
\text { (Pankaru) }\end{array}$ & $\begin{array}{l}2006 \\
\text { Doutorado }\end{array}$ & $\begin{array}{l}\text { Linguística } \\
\text { (UFAL) }\end{array}$ & $\begin{array}{l}\text { Focaliza a estrutura da língua Ofayé e analisa a } \\
\text { sua importância sóciohistórica para a luta dos } \\
\text { povos indígenas. }\end{array}$ \\
\hline $\begin{array}{l}\text { Justino } \\
\text { Sarmento } \\
\text { Rezende } \\
\text { (Tuyuka) }\end{array}$ & $\begin{array}{l}2007 \\
\text { Mestrado }\end{array}$ & $\begin{array}{l}\text { Educação } \\
\text { (UCDB) }\end{array}$ & $\begin{array}{l}\text { Estuda as práticas educativas escolares no } \\
\text { processo de fortalecimento da identidade Tuyuka } \\
\text { focalizando a escola indígena municipal } \\
\text { Utãpinopona-Tuyuka }\end{array}$ \\
\hline $\begin{array}{c}\text { Eliane } \\
\text { Gonçalves de } \\
\text { Lima (Terena) }\end{array}$ & $\begin{array}{l}2008 \\
\text { Mestrado }\end{array}$ & $\begin{array}{l}\text { Educação } \\
\text { (UCDB) }\end{array}$ & $\begin{array}{l}\text { Pesquisa que observou, registrou e estudou os } \\
\text { processos próprios de aprendizagem no contexto } \\
\text { da pedagogia Terena, bem como os fatores que } \\
\text { contribuem para a construção dessa pedagogia nos } \\
\text { espaços em que a criança circula, como o núcleo } \\
\text { familiar, o contexto da comunidade e o espaço } \\
\text { escolar. }\end{array}$ \\
\hline $\begin{array}{l}\text { Nilza Leite } \\
\text { Antonio } \\
\text { (Terena) }\end{array}$ & $\begin{array}{l}2009 \\
\text { Mestrado }\end{array}$ & $\begin{array}{l}\text { Psicologia } \\
\text { (UCDB) }\end{array}$ & $\begin{array}{l}\text { Compreender alguns aspectos da identidade de } \\
\text { crianças em processo de escolarização, no } \\
\text { contexto de sua rede social. O lócus da pesquisa } \\
\text { foi a Escola Municipal Indígena Pólo "General } \\
\text { Rondon", na Aldeia Terena Bananal Distrito de } \\
\text { Taunay - Aquidauana, MS }\end{array}$ \\
\hline $\begin{array}{l}\text { Edílson Martins } \\
\text { Melgueiro } \\
\text { (Baniwa) }\end{array}$ & $\begin{array}{c}2009 \\
\text { Mestrado }\end{array}$ & $\begin{array}{l}\text { Linguística } \\
\text { (UnB) }\end{array}$ & $\begin{array}{l}\text { Investigação linguística dos classificadores } \\
\text { nominais da língua Baníwa do Içana, visando } \\
\text { contribuir para o aprofundamento do } \\
\text { conhecimento linguístico desse importante aspecto } \\
\text { da gramática dessa língua Aruák. }\end{array}$ \\
\hline $\begin{array}{l}\text { Tonico Benites } \\
\text { (Kaiowá) }\end{array}$ & $\begin{array}{c}2009 \\
\text { Mestrado }\end{array}$ & $\begin{array}{l}\text { Antropologia } \\
\text { Social } \\
\text { (UFRJ) }\end{array}$ & $\begin{array}{l}\text { Analisa as divergências e conflitos entre a } \\
\text { educação Kaiowá realizada pelas famílias } \\
\text { extensas, e a escola formal introduzida nas aldeias, } \\
\text { utilizando-se do conceito de "tradição de } \\
\text { conhecimento" (Barth) como uma ferramenta } \\
\text { analítica. }\end{array}$ \\
\hline $\begin{array}{l}\text { Rita Gomes do } \\
\text { Nascimento } \\
\text { (Potiguara) }\end{array}$ & $\begin{array}{c}2010 \\
\text { Doutorado }\end{array}$ & $\begin{array}{c}\text { Educação } \\
\text { (UFRN) }\end{array}$ & $\begin{array}{l}\text { Analisa as práticas educativas nas escolas } \\
\text { diferenciadas Tapeba, focalizando as } \\
\text { manipulações táticas e estratégicas do tema do } \\
\text { preconceito em suas pedagogias. }\end{array}$ \\
\hline $\begin{array}{l}\text { Daniel } \\
\text { Munduruku } \\
\text { Monteiro Costa } \\
\text { (Munducuru) }\end{array}$ & $\begin{array}{c}2010 \\
\text { Doutorado }\end{array}$ & $\begin{array}{l}\text { Educação } \\
\text { (USP) }\end{array}$ & $\begin{array}{l}\text { Enfoca o movimento indígena brasileiro sob a } \\
\text { ótica do caráter educativo desde sua origem como } \\
\text { um instrumento legítimo na defesa dos direitos } \\
\text { indígenas e que, estruturado em seu processo de }\end{array}$ \\
\hline
\end{tabular}




\begin{tabular}{|c|c|c|c|}
\hline & & & $\begin{array}{l}\text { autoformação, também serviu para promover } \\
\text { mudança no olhar da sociedade brasileira sobre os } \\
\text { povos indígenas. }\end{array}$ \\
\hline $\begin{array}{l}\text { Florêncio Vaz } \\
\text { Almeida Filho } \\
\text { (Maytapu) }\end{array}$ & $\begin{array}{c}2010 \\
\text { Doutorado }\end{array}$ & $\begin{array}{c}\text { Ciências Sociais } \\
\text { (UFBA) }\end{array}$ & $\begin{array}{l}\text { Etnografia do processo de formação de } \\
\text { identidades étnicas indígenas que está ocorrendo } \\
\text { no baixo rio Tapajós, no Oeste do Pará, } \\
\text { envolvendo } 40 \text { comunidades ribeirinhas } \\
\text { resultantes do processo de catequese e colonização } \\
\text { que se iniciou ainda no século XVII, que já foi } \\
\text { chamado de "caboclização". }\end{array}$ \\
\hline $\begin{array}{l}\text { Celinho } \\
\text { Belizário } \\
\text { (Terena) }\end{array}$ & $\begin{array}{c}2010 \\
\text { Mestrado }\end{array}$ & $\begin{array}{c}\text { Educação } \\
\text { (UCDB) }\end{array}$ & $\begin{array}{l}\text { Análise a experiência de uma escola indígena } \\
\text { Terena na aldeia Cachoeirinha, no município de } \\
\text { Miranda,em Mato Grosso do Sul. }\end{array}$ \\
\hline $\begin{array}{l}\text { Celma } \\
\text { Francelino } \\
\text { Fialho } \\
\text { (Terena) }\end{array}$ & $\begin{array}{c}2010 \\
\text { Mestrado }\end{array}$ & $\begin{array}{c}\text { Educação } \\
\text { (UCDB) }\end{array}$ & $\begin{array}{l}\text { Investigou os motivos que levaram a comunidade } \\
\text { Terena da Aldeia Ipegue a não assegurar o uso da } \\
\text { língua Terena, como primeira língua, e quais as } \\
\text { consequências deste desuso como fator de relação } \\
\text { interna na aldeia agregando grupos ou não, } \\
\text { fortalecendo valores étnicos e culturais, bem como } \\
\text { na relação com as demais aldeias. }\end{array}$ \\
\hline $\begin{array}{l}\text { Maria de } \\
\text { Lourdes Silva } \\
\text { Sobrinho } \\
\text { (Terena) }\end{array}$ & $\begin{array}{c}2010 \\
\text { Mestrado }\end{array}$ & $\begin{array}{c}\text { Educação } \\
\text { (UCDB) }\end{array}$ & $\begin{array}{l}\text { Analisa a alfabetização na língua terena, } \\
\text { discutindo a construção de sentido e significado a } \\
\text { partir de uma experiência realizada, no } 1^{\circ} \text { ano do } \\
\text { ensino fundamental na aldeia Cachoeirinha, em } \\
\text { Mato Grosso do Sul. }\end{array}$ \\
\hline $\begin{array}{l}\text { Wanderley Dias } \\
\text { Cardoso } \\
\text { (Terena) }\end{array}$ & $\begin{array}{c}2011 \\
\text { Doutorado }\end{array}$ & $\begin{array}{l}\text { História } \\
\text { (PUC-RS) }\end{array}$ & $\begin{array}{l}\text { Busca compreender até que ponto o ensino médio } \\
\text { oferecido aos Terena satisfaz as demandas e } \\
\text { expectativas da comunidade. }\end{array}$ \\
\hline $\begin{array}{l}\text { Gersem José } \\
\text { dos Santos } \\
\text { Luciano } \\
\text { (Baniwa) }\end{array}$ & $\begin{array}{c}2011 \\
\text { Doutorado }\end{array}$ & $\begin{array}{l}\text { Antropologia } \\
\text { (UnB) }\end{array}$ & $\begin{array}{l}\text { Analisa a demanda dos povos indígenas do Alto } \\
\text { Rio Negro por educação escolar e universitária e o } \\
\text { lugar que a escola e o mundo moderno ocupam no } \\
\text { imaginário atual desses povos, a partir do qual } \\
\text { projetam e constroem seu futuro. }\end{array}$ \\
\hline $\begin{array}{l}\text { Aquilino } \\
\text { Tsere'ubu'õ } \\
\text { Tsi'rui'a } \\
\text { (Xavante) }\end{array}$ & $\begin{array}{c}2012 \\
\text { Mestrado }\end{array}$ & $\begin{array}{c}\text { Educação } \\
\text { (UCDB) }\end{array}$ & $\begin{array}{l}\text { Analisa a Escola Xavante na Terra Indígena } \\
\text { Marãiwatsédéa partir da pedagogia Xavante com } \\
\text { base em três princípios: as histórias antigas, } \\
\text { religião e tradição. Os objetivos da pesquisa são: } \\
\text { compreender a organização educacional Xavante } \\
\text { modificada por influência das ressignificações ao } \\
\text { longo do tempo; identificar os significados } \\
\text { culturais da sociedade Xavante; observar a } \\
\text { organização social da comunidade Xavante } \\
\text { praticada na convivência e relações de parentesco; } \\
\text { analisar a proposta pedagógica das escolas e o } \\
\text { ensino da cultura Xavante. }\end{array}$ \\
\hline $\begin{array}{l}\text { Eliel Benites } \\
\text { (Kaiowá) }\end{array}$ & $\begin{array}{c}2014 \\
\text { Mestrado }\end{array}$ & $\begin{array}{c}\text { Educação } \\
\text { (UCDB) }\end{array}$ & $\begin{array}{l}\text { Descreve e analisa a trajetória do processo de } \\
\text { desconstrução e reconstrução da Educação Escolar } \\
\text { Indígena na Reserva IndígenaTe'ýikue, buscando } \\
\text { compreender como os processos próprios de } \\
\text { ensino e aprendizagemsão contemplados, } \\
\text { favorecendo, dessa forma, maior aproximação e } \\
\text { diálogo com os conhecimentos tradicionais. }\end{array}$ \\
\hline
\end{tabular}

Fonte: Elaborada pelos autores com base em Luciano (2011), Vargas e Castro (2013) e Vianna et al (2014). 
Para Luciano (2011, p. 54), a inserção dos indígenas na pós-graduação muito se deve à contribuição da Fundação Ford no Brasil, que em parceria com a Fundação Carlos Chagas passou a oferecer, a partir de 2002, bolsas anuais de mestrado e doutorado no país tendo como beneficiários aqueles que faziam parte de grupos sociais com pouco acesso ao ensino superior e que demonstrassem potencial de liderança em seus campos de atuação, entre os quais se encontravam os estudantes indígenas.

O Quadro 2 também mostra a concentração de trabalhos de pós-graduação na área de Educação $(n=12)$ dos quais sete foram defendidos na Universidade Católica Dom Bosco (UCDB) em Mato Grosso do Sul, talvez devido ao fato observado por Vianna et al. (2014, p.28) de que o mestrado em Educação da UCDB “é, possivelmente, o curso de pósgraduação stricto sensu em que há maior incidência de indígenas na realidade brasileira atual”. Esses autores ainda comentam que por se tratar de programas de pós-graduação em que há cobrança de mensalidades, a obtenção de bolsas concedidas pela Fundação Ford é condição praticamente indispensável para que os indígenas possam cursar a pós-graduação.

\section{Livros e coletâneas sobre educação indígena: 1970-2017}

Ao longo do século XX, nos estudos do pensamento social brasileiro, questões como raça e etnia foram tratadas de diferentes perspectivas em estudos sociológicos, antropológicos, históricos, literários, culturais, entre outras. Essas visões estão consolidadas nas obras de vários intelectuais que refletiram sobre a presença e o papel dos indígenas na formação da sociedade e cultura brasileiras, entre eles: Gilberto Freyre; Florestan Fernandes; Sérgio Buarque de Holanda; Darcy Ribeiro; Roberto Cardoso de Oliveira; Roberto Da Matta; Roque de Barros Laraia; Manuela Carneiro da Cunha; Eduardo Viveiros de Castro; Ronaldo Vainfas; Alfredo Bosi; John Manuel Monteiro; Pedro Paulo Funari e Francisco Silva Noeli; Bartomeu Meliá, apenas para ficar nos autores que são referência nos estudos sobre os povos indígenas do Brasil. E, é claro, sem desconsiderar, por exemplo, os estudos pioneiros de Lévi-Strauss realizados por meio da observação da cultura e hábitos desses povos, bem como os trabalhos de outros estudiosos que se dedicaram a investigar as comunidades indígenas brasileiras. Nessas obras podem ser buscadas as inúmeras teorias que elegeram a figura do índio no Brasil como parte da formação da sociedade brasileira e o espaço mutante que eles têm ocupado nessa sociedade, como argumenta Cohn (2001). 
Por sua vez, na literatura brasileira a temática indígena pode ser buscada desde os escritos dos cronistas e colonizadores, e em todas as demais fases da literatura. Dessa perspectiva, uma contribuição interessante é dada no estudo realizado por Santos (2009). A autora apresenta um interessante painel da imagem do índio na literatura brasileira, analisando desde a carta de Caminha, passando pelas vozes da época da colonização (José de Anchieta, Antonio Vieira e Basílio da Gama), do barroco (Gregório de Matos), dos românticos (Gonçalves Dias, José de Alencar, Bernardo Guimarães), até chegar ao modernismo (Oswald de Andrade, Mário de Andrade, Raul Bopp, Manoel Cavalcanti Proença, João Guimarães Rosa, Antonio Callado e Darcy Ribeiro), o que permite compreender a representação do indígena na formação do sistema literário brasileiro. Contudo, a visão dessa seleção nos instiga a refletir sobre o próprio significado de literatura brasileira, uma vez que dela foram excluídas as materialidades literárias produzidas pelos próprios indígenas, desde as diversas manifestações da oralidade - por exemplo, os cânticos em rituais, ou as histórias transmitidas de geração a geração - até outras formas de expressão escrita próprias desses povos.

A despeito desses múltiplos olhares sobre os indígenas brasileiros, a seguir serão apresentados e descritos três livros publicados que focalizaram a questão indígena sob o ponto de vista da educação, além de coletâneas organizadas a partir dos anos 1980 .

No levantamento de Capacla (1995) e nas bibliografias organizadas nos dossiês temáticos sobre educação indígena organizados no periódico Em Aberto (INEP/MEC), de 1984 e 1994 são destacados dois livros que abordam a questão da educação indígena, publicados na segunda metade dos anos 1970: o de Sílvio Coelho dos Santos (1975) e Bartomeu Melià (1979).

O livro de Silvio Coelho dos Santos, intitulado Educação e sociedades tribais, foi baseado em uma pesquisa realizada junto a postos indígenas da região Sul no início da década de 1970. Ao analisar essa obra, Capacla (1995, p. 19) explica que o autor:

[...] demonstra que aqueles povos estavam submetidos à dominação e à dependência aos órgãos governamentais e aos sistemas de produção e consumo da sociedade envolvente. A escolarização foi sistematicamente iniciada na região já na década de 40 mas, de acordo com o autor, seus resultados redundavam geralmente em fracasso e só reforçavam a dominação e submissão, por serem desconectados da realidade e serem monolíngues em português. Diante disso, em sua análise, ele não considerava a alfabetização como prioritária, nem acreditava que a educação por si só trouxesse mudanças; propunha, assim, um projeto maior, com atividades na área econômica, de saúde e etc., da qual a 
educação seria também um dos elementos. $O$ objetivo seria, principalmente, incentivar a auto-suficiência e iniciativa entre os índios.

Quanto ao livro de Melià, intitulado Educação indígena e alfabetização, a publicação foi baseada em um seminário organizado pelo Conselho Indigenista Missionário (CIMI), ocorrido em 1978, no final de uma década marcada pela intensa e crescente mobilização indígena. A partir das discussões realizadas nesse seminário, Melià

[...] lança o termo "educação para o indígena", ressaltando assim que as sociedades indígenas já possuem seu próprio sistema educacional, ao qual a educação escolar deveria se justapor, e não substituir. Aprofunda a discussão da questão sobre a língua em que a alfabetização deveria se dar, lançada já no livro de Coelho dos Santos; esta discussão tem sido um dos temas pedagógicos centrais até hoje, e Melià propõe à época que, com raras exceções, ela deva se dar na língua indígena e não deve ser abandonada nos anos seguintes da escolarização. Lança também questões relativas aos conteúdos e materiais didáticos que deveriam ser utilizados nesta nova proposta de escola indígena. Configura-se a partir daqui, portanto, um novo momento da escola indígena, em que começam a ser discutidas alternativas à educação escolar até então oferecida aos índios. (CAPACLA, 1995, p. 19-20)

O ponto fulcral dessa obra de Melià (1979) é a distinção entre educação indígena e educação escolar indígena, no contexto do uso da escrita em sociedades ágrafas como forma de dominação.

Capacla (1995) ainda destaca outro livro, de autoria de Isabel Hernández (1981) e intitulado Educação e sociedade indígena, em que a autora descreve uma experiência educacional realizada no Chile, entre 1972 e 1973, junto aos povos Mapuche, e que teve grande repercussão no Brasil, pois apresentava a aplicação bilíngue do método de Paulo Freire. Essa experiência, conforme explica Capacla (1995, p. 23)

[...] fazia parte de um programa mais amplo de mobilização do povo Mapuche, mas que foi extinta em setembro de 73 após o golpe de Estado. Este programa tinha como objetivo superar a situação de discriminação e exploração deste povo pela sociedade chilena - que a autora analisava ser uma situação de classe e de discriminação étnica - através de sua autoafirmação étnica, estimulando sua auto-organização social; além da bialfabetização (alfabetização simultânea nas duas línguas), outros.

A partir da década de 1980 outros livros foram publicados, com destaque especial para várias coletâneas que apresentam diferentes visões sobre a educação indígena, inclusive com a presença de textos de autores indígenas. O Quadro 3 sintetiza essa produção científica com um breve panorama das obras publicadas. 
Quadro 3: Livros e coletâneas sobre educação indígena (1981-2017)

\begin{tabular}{|c|c|}
\hline Autores/Ano & $\begin{array}{l}\text { Escopo do Trabalho } \\
\end{array}$ \\
\hline $\begin{array}{l}\text { Comissão Pró- } \\
\text { Índio-SP (1981) }\end{array}$ & $\begin{array}{l}\text { Coletânea de trabalhos apresentados no Encontro Nacional sobre Educação Indígena, } \\
\text { SP - 1979- Marco referencial, pois faz a defesa da educação bilíngue nas escolas } \\
\text { indígenas. }\end{array}$ \\
\hline Silva (1987) & $\begin{array}{l}\text { Coletânea com } 9 \text { artigos divididos em duas partes: análise crítica das representações } \\
\text { acerca das populações indígenas em livros didáticos; e outra, de propostas oferecidas } \\
\text { a professores composta de conceitos antropológicos e de procedimentos pedagógicos } \\
\text { para que conduzisse sua prática em sala de aula }\end{array}$ \\
\hline $\begin{array}{l}\text { Cabral; Monte; } \\
\text { Monserrat (1987) }\end{array}$ & $\begin{array}{l}\text { Relatam experiências educacionais junto a comunidades indígenas do Acre } \\
\text { Propunha refletir sobre a pluralidade cultural do país, buscando dessa forma uma } \\
\text { educação brasileira contemporânea que a respeitasse. }\end{array}$ \\
\hline $\begin{array}{c}\text { Emiri; } \\
\text { Monserrat (1989) }\end{array}$ & $\begin{array}{l}\text { Coletânea de trabalhos apresentados em encontros realizados pela Operação Anchieta } \\
\text { (OPAN), com discussões sobre questões de alfabetização na língua materna, o } \\
\text { trabalho pedagógico partindo da realidade da comunidade, a preocupação com a } \\
\text { formação de monitores indígenas e com a criação de uma escola autônoma } \\
\text { autogerida. }\end{array}$ \\
\hline Seki (1993) & $\begin{array}{l}\text { Coletânea de trabalhos apresentados em seminário realizado em } 1991 \text { na Unicamp. } \\
\text { Discutem tanto questões linguísticas numa situação de contato, como também } \\
\text { questões educacionais, com artigos muito variados, cobrindo uma extensão } \\
\text { geográfica e cultural. }\end{array}$ \\
\hline $\begin{array}{l}\text { Grupioni } \\
(1994)\end{array}$ & $\begin{array}{l}\text { Coletânea de } 19 \text { ensaios organizados nas seguintes partes: Os índios e a secretaria } \\
\text { municipal de cultura; A descoberta da América e o encontro com o outro; } \\
\text { Diversidade cultural das sociedades indígenas; Índios do presente e do futuro; } \\
\text { Catálogo da Exposição "Índios no Brasil". }\end{array}$ \\
\hline $\begin{array}{l}\text { Silva; Grupioni } \\
\quad \text { (1995) }\end{array}$ & $\begin{array}{l}\text { Coletânea de } 20 \text { artigos que procuram estimular a reflexão critica de professores e } \\
\text { estudantes quanto ao lugar e a imagem dos índios nos currículos e nos manuais } \\
\text { escolares, ao mesmo tempo em que buscam oferecer sugestões pedagógicas e de } \\
\text { postura para o tratamento da questão indígena na escola. }\end{array}$ \\
\hline $\begin{array}{l}\text { D’Angelis; } \\
\text { Veiga (1997) }\end{array}$ & $\begin{array}{l}\text { Coletânea de trabalhos apresentados nos Encontros sobre Leitura e Escrita em } \\
\text { Sociedades Indígenas, no âmbito do Congresso de Leitura no Brasil (COLE). }\end{array}$ \\
\hline Secchi (1998) & $\begin{array}{l}\text { Coletânea com trabalhos apresentados na Conferência Ameríndia de Educação e } \\
\text { Congresso de Professores indígenas. }\end{array}$ \\
\hline $\begin{array}{l}\text { Veiga; Salanova } \\
\quad(2001)\end{array}$ & $\begin{array}{l}\text { Coletânea de trabalhos apresentados nos Encontros sobre Leitura e Escrita em } \\
\text { Sociedades Indígenas, no âmbito do Congresso de Leitura no Brasil. }\end{array}$ \\
\hline $\begin{array}{l}\text { Grupioni; Vidal; } \\
\text { Fischman (2001) }\end{array}$ & $\begin{array}{l}\text { Coletânea de ensaios apresentados no Seminário Internacional "Ciência, cientistas e } \\
\text { tolerância", realizado na USP, em } 1997 \text {. }\end{array}$ \\
\hline $\begin{array}{l}\text { Silva; Ferreira } \\
\quad \text { (2001a) }\end{array}$ & $\begin{array}{l}\text { Descreve e analisa projetos e experiências escolares sobre a escola indígena buscando } \\
\text { respostas para questões como: Qual o lugar da escola na vida de um povo indígena } \\
\text { no Brasil de hoje? Que princípios educativos e quais práticas pedagógicas fazem da } \\
\text { escola uma escola indígena? }\end{array}$ \\
\hline $\begin{array}{l}\text { Silva; Ferreira } \\
\quad(2001 b)\end{array}$ & $\begin{array}{l}\text { Coletânea de } 14 \text { artigos com experiências de escolarização vivenciada por diferentes } \\
\text { grupos indígenas do Brasil. Organizado em quatro partes: educação, antropologia } \\
\text { diversidade; história, conhecimento e estética; projetos de autonomia indígena; } \\
\text { questões de linguística indígena. }\end{array}$ \\
\hline Ferreira (2002) & $\begin{array}{l}\text { Reúne relatos sobre a atividade matemática no país e no exterior dentro de uma } \\
\text { perspectiva pluricultural. Os textos visam proporcionar subsídios para professores } \\
\text { avaliarem práticas e formularem programas de ensino diferenciados. }\end{array}$ \\
\hline Grupioni (2002) & $\begin{array}{l}\text { Apresenta tabelas e listas sobre os povos indígenas no Brasil, apresenta informações } \\
\text { quantitativas sobre etnias, população, línguas, terras, escolas, alunos e professores } \\
\text { indígenas, como subsídio para a realização de atividades propostas no âmbito do } \\
\text { Programa Parâmetros em Ação de Educação Escolar Indígena e de apoio à leitura e } \\
\text { compreensão do Mapa das Terras Indígenas no Brasil. }\end{array}$ \\
\hline $\begin{array}{l}\text { Silva, Nunes; } \\
\text { Macedo (2002) }\end{array}$ & $\begin{array}{l}\text { Nove textos com estudos sobre crianças em contextos indígenas e seus problemas de } \\
\text { aprendizado e socialização. }\end{array}$ \\
\hline Marfan (2002) & $\begin{array}{l}\text { Coletânea de quinze trabalhos apresentados no } 1^{\circ} \text {. Congresso Brasileiro de } \\
\text { Qualidade em Educação - Formação de professores promovido pela SEF/MEC. }\end{array}$ \\
\hline
\end{tabular}




\begin{tabular}{|c|c|}
\hline $\begin{array}{c}\text { Veiga; } \\
\text { D’Angelis(2003) }\end{array}$ & $\begin{array}{l}\text { Trabalhos apresentados nos Encontros sobre Leitura e Escrita em Sociedades } \\
\text { Indígenas, no âmbito do COLE (Congresso de Leitura no Brasil) }\end{array}$ \\
\hline IBASE (2004) & $\begin{array}{l}\text { Três ensaios que procuram fazer o elo entre o passado e o futuro dos remanescentes } \\
\text { de povos indígenas no Brasil, tendo a educação escolar indígena como fio condutor. }\end{array}$ \\
\hline $\begin{array}{l}\text { Lima; Hoffmann } \\
\text { (2004) }\end{array}$ & $\begin{array}{l}\text { Intervenções realizadas no seminário Desafios para uma educação superior para os } \\
\text { povos indígenas no Brasil, realizado em Brasília. }\end{array}$ \\
\hline $\begin{array}{l}\text { Veiga; Ferreira } \\
(2005)\end{array}$ & $\begin{array}{l}\text { Contém nove trabalhos apresentados nos Encontros sobre Leitura e Escrita em } \\
\text { Sociedades Indígenas, no âmbito do COLE (Congresso de Leitura no Brasil) }\end{array}$ \\
\hline $\begin{array}{l}\text { Pagliaro; } \\
\text { Azevedo; Santos } \\
\text { (2005) }\end{array}$ & $\begin{array}{l}\text { Reúne oito artigos contendo análises demográficas de sociedades indígenas no Brasil } \\
\text { ou que relacionaram aspectos demográficos a dimensões de sua cultura, além de uma } \\
\text { entrevista com o antropólogo John Early. }\end{array}$ \\
\hline $\begin{array}{l}\text { Grupioni } \\
(2006)\end{array}$ & $\begin{array}{l}\text { Coletânea com doze capítulos que enfocam visões de antropólogos, linguistas, } \\
\text { pedagogos e professores indígenas sobre a educação escolar indígena e o desafio de } \\
\text { formar professores índios para atuarem nas escolas de suas aldeias. }\end{array}$ \\
\hline $\begin{array}{l}\text { Oliveira; Freire } \\
\quad(2006)\end{array}$ & $\begin{array}{l}\text { Aborda a presença e a participação dos indígenas no processo de formação do Brasil. } \\
\text { nos seguintes períodos: a) regime dos aldeamentos missionários (1549-1755); b) } \\
\text { assimilação e fragmentação (1755-1910); c) regime tutelar (1910-1988); cidadania } \\
\text { indígena (1988-2006). Integra a série Cadernos SECAD (volume 3). }\end{array}$ \\
\hline $\begin{array}{c}\text { Henriques; } \\
\text { Gesteira; Grillo; } \\
\text { Chamusca (2007) }\end{array}$ & $\begin{array}{l}\text { Aborda os marcos institucionais da educação escolar indígena, realiza um diagnóstico } \\
\text { dos sistemas de ensino e educação escolar indígena e analisa as políticas públicas, } \\
\text { programas e projetos para educação escolar indígena. }\end{array}$ \\
\hline $\begin{array}{l}\text { Luciano; Oliveira; } \\
\text { Hoffman (2010) }\end{array}$ & $\begin{array}{l}\text { Coletânea de cinco artigos que consolidam pesquisas de mestrado e doutorado } \\
\text { defendidas por acadêmicos indígenas de universidades de todo o Brasil entre os anos } \\
\text { de } 2008 \text { e } 2010 \text {. }\end{array}$ \\
\hline Lima (2012) & $\begin{array}{l}\text { Os seis capítulos abordam a história indígena, a importância da história oral para o } \\
\text { ensino e pesquisa em história indígena; a relação entre educação indígena e a história } \\
\text { crítica à luz de Karl Marx e do marxismo; e da história indígena no e do Brasil. }\end{array}$ \\
\hline $\begin{array}{c}\text { Paladino; } \\
\text { Almeida (2012) }\end{array}$ & $\begin{array}{l}\text { Apresenta uma reflexão a respeito das politicas educacionais voltadas ao } \\
\text { reconhecimento da diversidade durante os dois governos do presidente Luiz Inácio } \\
\text { Lula da Silva (2003-2010). }\end{array}$ \\
\hline $\begin{array}{c}\text { Tassinari; } \\
\text { Grando; Marcos } \\
\text { Albuquerque } \\
\text { (2012) }\end{array}$ & $\begin{array}{l}\text { Coletânea de quatorze textos que refletem sobre o papel da escola no processo de } \\
\text { educação de crianças indígenas, nas aldeias ou fora delas. Apresenta leituras nativas } \\
\text { do universo das crianças e dos jovens indígenas }\end{array}$ \\
\hline $\begin{array}{l}\text { Lima; Barroso- } \\
\text { Hoffmann (2013) }\end{array}$ & $\begin{array}{l}\text { Coletânea com doze textos com reflexões sobre os desafios implícitos nos debates } \\
\text { sobre a formação de indígenas no ensino superior no Brasil contemporâneo. Os } \\
\text { estudos são fruto da experiência de fomento à presença indígena nas universidades } \\
\text { durante a execução do projeto Trilhas de Conhecimento no período entre } 2004 \text { e } \\
2010 \text {. }\end{array}$ \\
\hline $\begin{array}{l}\text { Vianna; Ferreira; } \\
\text { Landa; Urquiza } \\
\quad \text { (2014) }\end{array}$ & $\begin{array}{l}\text { Focaliza a presença dos indígenas no ensino superior brasileiro a partir de } \\
\text { experiências do Programa Rede de Saberes em Mato Grosso do Sul. }\end{array}$ \\
\hline Lima (2016) & $\begin{array}{l}\text { Os sete textos abordam os resultados das demandas por educação superior por parte } \\
\text { dos povos indígenas do Brasil, e as ações e inações da administração pública e das } \\
\text { instituições de ensino superior nesse campo. }\end{array}$ \\
\hline $\begin{array}{l}\text { Andrade; Silva } \\
\quad(2017)\end{array}$ & $\begin{array}{l}\text { Coletânea de oito textos com reflexões sobre realidades, concepções e conceitos que } \\
\text { caracterizam a história e cultura dos povos indígenas no Brasil, com sugestões de } \\
\text { leituras e atividades didáticas para professores. }\end{array}$ \\
\hline
\end{tabular}

Fonte: Elaborada pelo autor baseado em Capacla (1995); Grupioni (2008); D’Angelis (2008)

Para Grupioni (2008) e Luciano (2011) essas primeiras coletâneas - editadas nos anos 1980 até o início dos anos 2000, possuem como traço comum o relato e reflexões de experiências concretas de implantação de escolas indígenas, produção de materiais didáticos, formação de professores e militância nessa área. Também apontam a entrada em cena de professores indígenas e a colaboração destes com relatos de suas experiências. 
Além dessas coletâneas que publicaram trabalhos apresentados em eventos também podem ser citadas outras publicações nessa modalidade que foram organizadas pela Secretaria de Educação Fundamental/Coordenação Geral de Apoio às Escolas Indígenas do Ministério da Educação, abordando diversos aspectos relacionados à temática da educação escolar indígena e formação de professores indígenas, publicadas entre 1998 e 2002 (BRASIL, 1998; 2002). A partir dos anos 2000 outras coletâneas são organizadas, apresentando trabalhos de grupos de pesquisa acadêmicos que desenvolvem projetos sobre educação indígena, entre eles o Grupo de Educação Indígena - Grupo Mari/USP, que contribuiu com vários volumes da série “Antropologia, História e Educação”.

Os projetos desenvolvidos pelo Laboratório de Pesquisas em Etnicidade, Cultura e Desenvolvimento - LACED/Museu Nacional/UFRJ resultaram em várias coletâneas publicadas na série "Trilhas do Conhecimento" abordando a problemática do ensino superior indígena. Foram cinco publicações editadas em 2006 e 2007 em parceria com a pela SECADI e reunidas na série "Via dos Saberes" que integra a coleção "Educação para Todos". Os textos dessas coletâneas abordam a formação de professores indígenas; presença dos povos indígenas na formação brasileira; linguística para a formação de professores indígenas na área de linguagem; direito e legislação indígena; e educação intercultural bilíngue.

\section{Balanços da produção científica sobre educação indígena: 1984-2016}

Outros tipos de publicações sobre educação indígena foram publicados entre $1984 \mathrm{e}$ 2003 em dossiês temáticos de periódicos científicos, como mostram os dados do Quadro 4 com a síntese desses trabalhos.

Quadro 4: Dossiês sobre educação indígena (1984-2003) em periódicos nacionais

\begin{tabular}{|c|c|}
\hline Periódico / Ano & Escopos dos dossiês \\
\hline $\begin{array}{l}\text { Em Aberto (INEP), v. 3, } \\
\text { n.21, } 1984\end{array}$ & $\begin{array}{l}5 \text { artigos que enfocam aspectos históricos e críticos sobre a política } \\
\text { indigenista no Brasil; um balanço crítico da educação proporcionada aos } \\
\text { grupos indígenas; as contribuições da linguística à educação dos povos } \\
\text { indígenas; a abordagem da análise do discurso aplicada à educação } \\
\text { indígena; a experiência de formação de monitores indígenas; Apresenta } \\
\text { duas resenhas e uma bibliografia temática, sem identificação do } \\
\text { organizador. }\end{array}$ \\
\hline $\begin{array}{l}\text { Em Aberto (INEP), v.14, } \\
\text { n.63, } 1994\end{array}$ & $\begin{array}{l}18 \text { artigos propositivos a respeito do que deveria ser o que se começou a } \\
\text { denominar "ensino diferenciado"; o texto das "Diretrizes para a política de } \\
\text { educação escolar indígena", do MEC (1993). Contém uma bibliografia } \\
\text { temática, compilada e organizada por Luís Otávio P. da Cunha, Cleide } \\
\text { Albuquerque Moreira e Maria Helena Gutemberg Caldas, técnicos da }\end{array}$ \\
\hline
\end{tabular}




\begin{tabular}{|l|l|}
\hline & FUNAI. \\
\hline $\begin{array}{l}\text { Cadernos CEDES, v.19, } \\
\text { n.49,1999 }\end{array}$ & $\begin{array}{l}7 \text { artigos contendo pontos de vista, reflexões e experiências sobre educação } \\
\text { indígena, interculturalidade, escola, e sobre o papel dos assessores nos } \\
\text { projetos de educação escritos por pesquisadores e docentes estreitamente } \\
\text { ligados à causa indígena. }\end{array}$ \\
\hline $\begin{array}{l}11 \text { artigos que debatem a expansão quantitativa e diversificação das } \\
\text { experiências de formação de professores indígenas no país e refletem sobre }\end{array}$ \\
$\begin{array}{l}\text { Em Aberto (INEP), v.20, } \\
\text { n.76, aprensão quanto à qualidade e adequação dessa expansão diante das } \\
\text { demandas indígenas específicas. Apresenta ainda uma resenha e uma } \\
\text { bibliografia temática compilada e organizada por Luís Donizete Benzi } \\
\text { Grupioni. }\end{array}$ \\
\hline
\end{tabular}

Fonte: Elaborado pelos autores

Além desses balanços publicados entre as décadas de 1980 e 2000 a temática da educação indígena também tem encontrado espaço em dossiês organizados por outros periódicos científicos brasileiros, conforme mostram os dados do Quadro 5.

Quadro 5: Educação indígena em dossiês e periódicos científicos (2010-2015)

\begin{tabular}{|c|c|}
\hline Periódico/Ano & Escopo dos dossiês \\
\hline $\begin{array}{l}\text { Revista da FAEEBA } \\
\text { (UNEB), v. 19, n.33, } \\
2010\end{array}$ & $\begin{array}{l}\text { Apresenta um dossiê temático sobre educação indígena composto de } 13 \\
\text { artigos de pesquisadores do Brasil e exterior, e de pesquisadores indígenas } \\
\text { estruturado em três eixos temáticos: a) políticas de educação indígena: } \\
\text { estado e movimentos sociais; b) sociedades e culturas indígenas sob o } \\
\text { marco da educação escolar diferenciada; c) escola indígena e suas práticas. }\end{array}$ \\
\hline $\begin{array}{l}\text { Revista Pós-Ciências } \\
\text { Sociais (UFMA), v. } 7 \\
\text { n. } 14,2010\end{array}$ & $\begin{array}{l}\text { A temática abordada nos seis artigos são os povos indígenas e os processos } \\
\text { educacionais, por meio do relato de pesquisas antropológicas voltadas para } \\
\text { a educação e os povos indígenas, que abordam os impactos e } \\
\text { transformações gerados por processos de educação escolar e não escolar em } \\
\text { povos indígenas. }\end{array}$ \\
\hline $\begin{array}{l}\text { Práxis Educativa } \\
\text { (UEPG), v.7, n. esp., } \\
2012\end{array}$ & $\begin{array}{l}\text { Dossiê composto de } 12 \text { textos sobre educação indígena de pesquisadores de } \\
\text { instituições brasileiras e estrangeiras com pesquisas sobre aspectos da } \\
\text { educação bilíngue e intercultural e de questões relativas à escola, à presença } \\
\text { indígena no ensino superior e às representações sobre os povos indígenas. }\end{array}$ \\
\hline $\begin{array}{l}\text { História Hoje: Revista de } \\
\text { História e Ensino } \\
\text { (ANPUH), v. 1, n.2, } \\
2012\end{array}$ & $\begin{array}{l}\text { Apresenta cinco textos que tomados em conjunto dão relevo à } \\
\text { complexidade dos processos que apontam para o crescente protagonismo } \\
\text { dos povos indígenas e, ao mesmo tempo, redimensionam os debates e } \\
\text { desafios que cercam tanto as diferentes tentativas de escolarização quanto } \\
\text { aqueles relacionados à Lei } 11.645 / 2008 \text {. Traz uma entrevista com o } \\
\text { pesquisador baniwa Gersem José dos Santos Luciano sobre as trajetórias } \\
\text { das populações do Alto Rio Negro e um relato de experiências no ensino de } \\
\text { história e a questão indígena. }\end{array}$ \\
\hline $\begin{array}{l}\text { Século XXI: Revista de } \\
\text { Ciências } \quad \text { Sociais } \\
\text { (UFSM), v. 3, n.1, } 2013\end{array}$ & $\begin{array}{l}\text { Intitulado "Educação indígena: uma abordagem antropológica" o dossiê } \\
\text { reúne oito textos de cunho antropológico que refletem sobre a pluralidade } \\
\text { de experiências de escolarização relativas à questão indígena brasileira e } \\
\text { latino-americana, bem como sobre experiências de educação não escolar } \\
\text { relacionados aos ditos saberes tradicionais, em diferentes contextos } \\
\text { multiculturais. Traz ainda o texto da conferência proferida por Bartomeu } \\
\text { Meliá no I Seminário de Educação Indígena da UFSM, realizado em 2012, } \\
\text { em que a partir de sua experiência como etnólogo entre diversos povos } \\
\text { latino-americanos o autor propõe uma caminha de estranhamento em busca } \\
\text { dos sentidos da história da educação para os povos indígenas. }\end{array}$ \\
\hline
\end{tabular}




\begin{tabular}{|l|l|}
\hline $\begin{array}{l}\text { Revista Fórum } \\
\text { Identidades } \quad \text { Grupo } \\
\text { GEPIADDE-Itabaiana), } \\
\text { v.16, n.16, 2014 }\end{array}$ & $\begin{array}{l}\text { Com doze artigos o dossiê aborda a temática da educação dos povos } \\
\text { indígenas em articulação com as orientações da legislação educacional } \\
\text { brasileira. Os temas tratados são: educação indígena, educação escolar } \\
\text { indígena, políticas afirmativas para os povos indígenas na educação } \\
\text { superior, inclusão de conhecimentos indígenas na educação, Lei } \\
11.645 / 2008 \text { e História da Cultura dos povos indígenas. }\end{array}$ \\
\hline $\begin{array}{l}\text { Revista pedagógica } \\
\text { (UNOCHAPECÓ), v.17, } \\
\text { n.34, 2015. }\end{array}$ & $\begin{array}{l}\text { A educação indígena é enfocada no dossiê com doze artigos que abordam as } \\
\text { práticas escolares, as pedagógicas escolares e não-escolares, a educação } \\
\text { bilíngue, a inserção no ensino em diferentes níveis de ensino, práticas } \\
\text { culturais e sociais diversas (cerimônias, lazer, jogos, etc.) }\end{array}$ \\
\hline $\begin{array}{l}\text { Apresenta nove artigos sobre educação indígena que discutem questões } \\
\text { relacionadas aos desafios e demandas dos povos indígenas por educação, } \\
\text { em todos os níveis, assim como a incidência da educação na luta desses } \\
\text { povos e processos de formação de professores. Traz ainda uma entrevista } \\
\text { com Luís Donizete Benzi Grupioni, antropólogo e pesquisador da temática } \\
\text { educação indígena. }\end{array}$ \\
\hline
\end{tabular}

Fonte: Elaborado pelos autores

Além desses dossiês também é válido destacar a Revista Tellus, periódico especializado na temática indígena vinculada ao Núcleo de Estudos e Pesquisas das Populações Indígenas (NEPPI) da Universidade Católica Dom Bosco (UCDB). A revista publica artigos relacionados à etnologia indígena ou estudos interdisciplinares que tenham interface com a antropologia, além de possibilitar a divulgação de textos escritos por autores indígenas. A primeira edição é de 2001 e desde então já publicou 16 volumes com duas edições anuais cada. Uma busca nessas edições com o termo "educação indígena" resultou em 51 artigos que abordam essa temática.

Ainda no âmbito dos periódicos científicos, a revista Cadernos de Educação Escolar Indígena $-3^{o}$. Grau Indígena, editada sob a tutela da Universidade do estado de Mato Grosso (UNEMAT) e publicada desde 2002, tem como objetivo divulgar artigos produzidos pelos estudantes e docentes dos cursos, bem como outras contribuições de diferentes especialistas na área de educação indígena, dentro e fora do país, e desde então já publicou 12 edições.

Os pesquisadores da área também realizaram trabalhos do tipo "balanço" da produção científica sobre educação indígena publicados em diversos periódicos entre 1995 e 2016, conforme mostram os dados do Quadro 6, que apresenta a fonte de dados e o período de abrangência desses estudos, além do escopo e principais achados das pesquisas realizadas. 
Quadro 6: Artigos do tipo "balanço" sobre a produção científica em educação indígena

\begin{tabular}{|c|c|c|}
\hline Autor/Ano & $\begin{array}{l}\text { Fonte de dados e } \\
\text { período de } \\
\text { abrangência }\end{array}$ & Escopo e principais achados \\
\hline Capacla (1995) & $\begin{array}{l}7 \text { livros, } 6 \text { dissertações } \\
\text { e teses }(1975-1995)\end{array}$ & $\begin{array}{l}\text { Reúne e analisa ensaios e teses publicados no Brasil } \\
\text { precedido de um texto introdutório. }\end{array}$ \\
\hline Grupioni (2003) & $\begin{array}{l}53 \text { Dissertações e } 21 \\
\text { teses (1978-2002) }\end{array}$ & $\begin{array}{l}\text { A maioria dos trabalhos tem como preocupação } \\
\text { central a problemática da presença da escola em terras } \\
\text { indígenas; outros, entretanto, tratam de questões mais } \\
\text { amplas que a educação escolar, ainda que tratem } \\
\text { tangencialmente da temática. }\end{array}$ \\
\hline D’Angelis (2008) & \begin{tabular}{lr}
\multicolumn{2}{l}{ Livros e coletâneas de } \\
apresentações & em \\
congressos & $(1981-$ \\
$2006)$ &
\end{tabular} & $\begin{array}{l}\text { Nessas publicações não aparecem balanços e } \\
\text { avaliações críticas dos projetos e experiências } \\
\text { escolares em andamento. Ao contrário, as análises são } \\
\text { otimistas e esperançosas, quando não, ufanistas. }\end{array}$ \\
\hline $\begin{array}{c}\text { Gobbi; Tassinari } \\
\text { (2009) }\end{array}$ & $\begin{array}{lr}\text { Livros, } & \text { teses, } \\
\text { dissertações, e } \operatorname{artigos} \\
(1966-2007)\end{array}$ & $\begin{array}{l}\text { Analisa o histórico das políticas educativas voltadas } \\
\text { para indígenas no século XX em relação a história das } \\
\text { pesquisas antropológicas na área de etnologia } \\
\text { indígena destacando os poucos trabalhos que se } \\
\text { dedicaram ao tema da educação indígena. }\end{array}$ \\
\hline $\begin{array}{l}\text { Santos; Siqueira } \\
\text { (2009) }\end{array}$ & $\begin{array}{l}159 \text { teses e dissertações } \\
\text { do Banco de Teses da } \\
\text { Capes e no inventário } \\
\text { elaborado por Grupioni } \\
(1978-2007)\end{array}$ & $\begin{array}{l}\text { Análise dos resumos de dissertações e teses sobre } \\
\text { educação indígena. Resultados confirmam as análises } \\
\text { de Grupioni (2003a) de que o campo da Educação } \\
\text { Indígena vem ocupando cada vez mais um lugar } \\
\text { privilegiado nas discussões que envolvem a definição } \\
\text { de políticas voltadas para a construção de um sistema } \\
\text { educacional específico para os povos indígenas. }\end{array}$ \\
\hline $\begin{array}{l}\text { Maciel; Silva } \\
(2009)\end{array}$ & $\begin{array}{l}16 \text { dissertações (1994- } \\
2001)\end{array}$ & $\begin{array}{l}\text { Apresenta, sinteticamente, os primeiros resultados de } \\
\text { um amplo estudo empreendido pelos autores sobre a } \\
\text { história da educação escolar indígena no Brasil, com } \\
\text { ênfase na Região Centro-Oeste, particularmente Mato } \\
\text { Grosso e Mato Grosso do Sul. }\end{array}$ \\
\hline $\begin{array}{l}\text { Bergamaschi } \\
(2012)\end{array}$ & $\begin{array}{l}44 \text { teses e } 135 \\
\text { dissertações }(2001- \\
\text { 2009) disponíveis no } \\
\text { Portal da CAPES }\end{array}$ & $\begin{array}{l}\text { A maioria desses trabalhos dialogam com as atuais } \\
\text { políticas de educação escolar que têm sido } \\
\text { implementadas em Terras Indígenas. A autoria de } \\
\text { alguns trabalhos é de pesquisadores indígenas. A área } \\
\text { de Educação é majoritária }\end{array}$ \\
\hline $\begin{array}{l}\text { Rodrigues; Rocha; } \\
\text { Rodrigues (2013) }\end{array}$ & $\begin{array}{l}49 \text { dissertações e } 3 \\
\text { teses do Banco de } \\
\text { Teses da CAPES, } 73 \\
\text { artigos de periódicos e } \\
6 \text { Trabalhos das } \\
\text { Reuniões da ANPED } \\
(1997-2012)\end{array}$ & $\begin{array}{l}\text { Levantamento das produções científicas sobre } \\
\text { formação indígena para a docência. Resultados } \\
\text { apontaram que no ano de } 2012 \text {, houve um grande } \\
\text { crescimento de produções acerca da temática e que, } \\
\text { das } 220 \text { etnias do país, apenas } 80 \text { delas foram } \\
\text { estudadas por pesquisadores. }\end{array}$ \\
\hline $\begin{array}{l}\text { Santos; Lopes } \\
(2014)\end{array}$ & $\begin{array}{l}24 \text { dissertações e } 2 \\
\text { teses no Banco de } \\
\text { Teses Capes, } 4 \text { artigos } \\
\text { na SciELO }\end{array}$ & $\begin{array}{l}\text { Analisa as publicações que abordam o tema Educação } \\
\text { Escolar Indígena. Observou-se que as pesquisas } \\
\text { discutiam a escolarização dos Índios e sua relação } \\
\text { com Cultura, Identidade Étnica, Formação de } \\
\text { Professor, Ensino de Ciências e Currículo. }\end{array}$ \\
\hline $\begin{array}{l}\text { Monteiro; Kahlil } \\
(2015)\end{array}$ & $\begin{array}{l}152 \text { artigos publicados } \\
\text { na Revista Amazônica } \\
\text { de Ensino de Ciências } \\
(2008-2013)\end{array}$ & $\begin{array}{l}\text { Identificou as pesquisas que buscaram contribuir para } \\
\text { o desenvolvimento do ensino de ciências nas escolas } \\
\text { indígenas do Amazonas. Os resultados mostraram um } \\
\text { número pouco expressivo de trabalhos preocupados } \\
\text { com as questões indígenas e o ensino de ciências, } \\
\text { representado por apenas um artigo. }\end{array}$ \\
\hline
\end{tabular}




\begin{tabular}{|c|c|c|}
\hline $\begin{array}{l}\text { Bonin; Ripoll; } \\
\text { Aguiar (2015) }\end{array}$ & $\begin{array}{l}14 \text { dissertações e teses } \\
\text { disponíveis nas } \\
\text { bibliotecas virtuais da } \\
\text { UFRGS, ULBRA e } \\
\text { UCDB (2001-2013) }\end{array}$ & $\begin{array}{l}\text { Mapeia e discute algumas tendências e enfoques } \\
\text { analíticos que vêm sendo conduzidos em teses e } \\
\text { dissertações do campo da Educação que se valem dos } \\
\text { Estudos Culturais para a abordagem da temática } \\
\text { indígena. Verificou que, em tais produções, } \\
\text { problematiza-se a ideia abstrata de diversidade } \\
\text { cultural mobilizada pelas perspectivas } \\
\text { multiculturalistas. Constatou que o campo dos } \\
\text { Estudos Culturais favorece o desenvolvimento de } \\
\text { análises críticas que focalizam as desigualdades, as } \\
\text { relações de poder, as práticas representacionais e as } \\
\text { políticas em torno das identidades/diferenças. }\end{array}$ \\
\hline $\begin{array}{l}\text { Oliveira; Zibetti } \\
\text { (2015) }\end{array}$ & $\begin{array}{lll}85 & \text { dissertações e } & 36 \\
\text { teses disponíveis } & \text { na } \\
\text { BDTD (1997-2014) } & \end{array}$ & $\begin{array}{l}\text { Estudo do tipo estado do conhecimento sobre as } \\
\text { temáticas escolarização e educação escolar indígena. } \\
\text { Os resultados mostraram que há poucos trabalhos na } \\
\text { área de psicologia e que, apesar das dificuldades e } \\
\text { contradições que a educação escolar indígena } \\
\text { apresenta em diferentes contextos no âmbito nacional, } \\
\text { os povos indígenas, ouvidos, atribuem um grande } \\
\text { valor à escola, lutando pela implantação, manutenção } \\
\text { e melhoria dessa instituição em suas aldeias, como } \\
\text { elemento fundamental para o fortalecimento de suas } \\
\text { identidades. }\end{array}$ \\
\hline Domingues (2016) & $\begin{array}{lr}3 & \text { artigos publicados } \\
\text { nas revistas Educação } \\
\& \quad \text { Realidade } & \mathrm{e} \\
\text { Currículo } & \text { sem } \\
\text { Fronteiras } & (2010, \\
2011,2014) & \end{array}$ & $\begin{array}{l}\text { Mapeamento dos debates políticos e epistemológicos } \\
\text { acerca da história indígena escolar que circulam nos } \\
\text { campos do currículo e do ensino de História. Conclui } \\
\text { pela quase ausência da temática indígena nas } \\
\text { pesquisas desta área, dado a existência de poucos } \\
\text { trabalhos. }\end{array}$ \\
\hline
\end{tabular}

Fonte: Elaborado pelos autores

Por fim, vale comentar que os balanços do Quadro 6 são relevantes contribuições para os estudos sobre educação indígena ao apontarem os enfoques, os temas mais pesquisados e as lacunas existentes nesse campo de conhecimento.

\section{Considerações finais}

Os resultados dessa revisão narrativa mostraram que os primeiros estudos de pósgraduação sobre educação indígena surgem no final da década de 1970, concomitantemente com os primeiros livros e coletâneas dessa temática. Já os primeiros trabalhos de pós-graduação realizados pelos indígenas só vão surgir a partir do ano de 1996. As décadas de 1980 e 1990 são marcadas pelo surgimento dos primeiros dossiês e artigos do tipo "balanço" da produção científica sobre a temática em questão.

As produções científicas em educação indígena já não são mais incipientes, uma vez que recuperamos um elevado conjunto de estudos de várias áreas do conhecimento, denotando que esse campo está constituído a partir de uma matriz interdisciplinar. 
Para futuras pesquisas sobre a produção científica dessa temática sugerimos que sejam consultadas outras bases de dados, contudo utilizando as mesmas expressões de busca, como forma de comparar os resultados obtidos. Igualmente, a utilização de outras metodologias, como, por exemplo, a biliometria, poderá produzir outros indicadores que ampliarão as análises dos resultados obtidos.

\section{REFERÊNCIAS}

ALVES, M. F.; OLIVEIRA, J. F. de. Pós-graduação no Brasil: do regime militar aos dias atuais. Revista Brasileira de Política e Administração da Educação, Goiânia-GO, v. 30, n. 2, p. 351-376, maio/ago. 2014.

BITTAR, M.; FERREIRA JUNIOR, A. Pluralidade lingüística, escola de bê-á-bá e teatro jesuítico no Brasil do século XVI. Educação e Sociedade, v. 25, p. 171-195, 2004.

BRASIL. Ministério da Educação e do Desporto. O governo brasileiro e a educação escolar indígena: 1995-2002. Brasília: MEC/SEF, 2002

CAPACLA, M. V. (Org.). O debate sobre a educação indígena no brasil (1975-1995): resenhas de teses e livros. Brasília: MEC, 1995

COHN, C. Educação escolar indígena: para uma discussão de cultura, criança e cidadania ativa. Revista Perspectiva, Florianópolis, v. 23, n. 2, p. 485-515, jul./dez. 2005.

COHN, C. Culturas em transformação: os índios e a civilização. São Paulo em Perspectiva, v. 15, n. 2, p. 36-42, 2001.

D'ANGELIS, W. da R. Educação escolar indígena? A gente precisa ver. Ciência e Cultura, v. 60, n. 4, p. 28-31, 2008.

FREIRE, J. R. B. Trajetória de muitas perdas e poucos ganhos. In: BRASIL. Educação escolar indígena em Terra Brasilis: tempo de novo descobrimento Rio de Janeiro: IBASE, 2004.

GRUPIONI, L. D. B. Experiências e Desafios na Formação de Professores Indígenas no Brasil. Em Aberto, Brasília, v. 20, n. 76, p. 13-18, fev. 2003a.

GRUPIONI, L. D. B. A Educação Indígena na Academia: inventário comentado de dissertações e teses sobre educação escolar indígena no Brasil (1978-2002). Em Aberto, Brasília, v. 20, n. 76, p. 197-238, fev. 2003b.

GRUPIONI, L. D. B. Olhar longe, porque o futuro é longe: cultura, escola e professores indígenas no Brasil. 2008, 240f. Tese (Doutorado em Antropologia Social) - Universidade de São Paulo, São Paulo, 2008. 
LUCIANO, G. J. dos S. Educação para manejo e domesticação do mundo entre a escola real e a escola ideal: os dilemas da educação escolar indígena no Alto Rio Negro. Brasília, 2011. 368 f. Tese (Doutorado em Antropologia) - Universidade de Brasília, Brasília, 2011.

MELIÀ, B. Educação indígena e alfabetização. São Paulo: Loyola, 1979.

OLIVEIRA, L. A. de; NASCIMENTO, R. G. do. Roteiro para uma história da educação escolar indígena: notas sobre a relação entre política indigenista e educacional. Educação e Sociedade, Campinas, v. 33, n. 120, Jul./Set. 2012.

ROTHER, E. T. Revisão narrativa X revisão sistemática. Acta Paulista de Enfermagem, v. 20, n. 2 , p. $5-6,2007$.

SANTOS, L. A. O. O percurso da indianidade na literatura brasileira: matizes da figuração. São Paulo: Cultura Acadêmica, 2009.

SILVA, A. R. da. Concepções e práticas de educação escolar indígena: institucionalidade, estado da arte e escolarização dos Tikuna no Alto Solimões-AM. 270 f. Tese. (Doutorado Sociedade e Cultura da Amazônia). Universidade Federal do Amazonas, Manaus, 2016.

VOSGERAU, D. S. R.; ROMANOWSKI, J. P. Estudos de revisão: implicações conceituais e metodológicas. Diálogo Educacional, Curitiba, v.14, n.21, p. 165-189, jan./abr. 2014.

\section{Como referenciar este artigo}

MAROLDI, Alexandre Masson.; MAIA LIMA, Luis Fernando.; HAYASHI, Maria Cristina Piumbato Innocentini. A produção científica sobre educação indígena no Brasil: uma revisão narrativa. Revista Ibero Americana de Estudos em Educação, Araraquara, v. 13, n. 3, p. 931-952, jul./set., 2018. E-ISSN:1982-5587. DOI: 10.21723/riaee.v13.n3.2018.10211

Submetido em: 01/08/2017

Revisões requeridas: 10/11/2017

Aprovado em: 04/05/2018 